\title{
V. On the Timbers suited for Railway Sleepers in South India
}

\section{Dr Cleghorn}

To cite this article: Dr Cleghorn (1863) V. On the Timbers suited for Railway Sleepers in South India, Transactions of the Botanical Society of Edinburgh, 7:1-4, 55-57, DOI: 10.1080/03746606309467800

To link to this article: http://dx.doi.org/10.1080/03746606309467800

册 Published online: 01 Dec 2010.

Submit your article to this journal $₫$

Џlll Article views: 3

Q View related articles $\sqsubset$ 


\section{Remarks on the Theory of the Metamorphosis of Plants. 55}

of new cells to the extremities, and to parts already formed, while nothing is added to the upper part of the appendages, or, in other words, that they grow from the base, an assertion which is only partially correct, as the more recent researches of Trecul show.* While admitting the claim that the axis has to be considered as the primary organ in many, perhaps the majority of instances, we yet think that, in the present imperfect state of our knowledge, as just a claim might be raised for the leaf as a primary organ in other cases. Thus, in plants that still consist of a mere congeries of cells, we often find those cells multiplying in such a manner as to produce a leaf-like expansion, as in Ulva and other Thallogens. A similar tendency is manifested in higher cryptogamous plants, as in Marchantia, or in the pro-embryos that result from the germination of the spores of ferns, \&c., where the leaf-form evidently precedes that of the axis.

In flowering plants the predominance of the primary leaf formation is shown in such cases as Lemna; and even in the embryo of dicotyledonous plants the eotyledons are but little in arrear of the axis in regard to their development, and may often be considered, at the period of germination, in advance even of the axis ; as also in many monocotyledonous plants. $t$

Some of the foregoing instanees may perhaps be cited as merely leaflike modifications of the axis, and may thus be considered like the leaflike branches of Opuntia, Xylophylla, Ruscus, \&c., as instances of analogy rather than of homology. But before the truth of this objection can unreservedly be admitted, the differenee between the axis and its appenclages, must be more distinctly defined than it is at present. Neither can we unconditionally subscribe to the assertion of Turpin, that there are no intermediate stages between stem and leaf, after the evidence afforded by the leaves of Guarea and Trichilia, where the leaves after a time assume the condition of the branches, and develop young leaflets from their free extremities. $f$ Many similar instances might be cited; but it is idle to attempt to define which of the two, leaf or axis, takes the greatest share in the metamorphosis. Rather may we not consider leaf and axis as parts of one and the same organ, that in most cases both parts are developed, and take part in the metamorphosis, while in other cases the one predominates over the other. Is not this view consistent with the absolute identity of original structure, and with what we know of cellular growth, in the vegetative organs of plants? Do not all these instances of nature's pliability, as manifested in the metamorphosis, afford a warning against those systematists who, relying upon some slight or inconstant variation in some one or more organs, found thereupon an unstable and unphilosophical assemblage of genera and species?

\section{Notice of Alga from the Faroe Islands. By Rosent Brown of Campster.}

V. On the Timbers suited for Railway Sleepers in South India. By Dr Cleghonn, Madras.

The author alluded to the enormous requirements of the Indian railways in the matter of timber for different purposes, especially sleepers.

* Ann. des Sc. Nat., $3^{\theta}$ Ser. Bot., vol. xx. p. 211.

† This predominance of the leaf over the axis is particularly striking in certain of the Cyrtandreæ, the germination of which has been described by Mr Crocker, in the Journal of the Linnean Society, vol. v. p. 65, 1860, and also by Dr Caspary of Königsberg. In these plants, says Mr Orocker, "there has not been the slightest attempt to produce a plumule."

† Dr Alexander, " Proc. Linn. Soc.," May 1852. 
This is a subject of great importance, but almost the only records row existing are a suggestive paper by Dr Falconer in the Journal of the Agricultural and Horticultural Society of India, and the Jury Reports of the Madras Exhibitions of 1855-57. A portion of the immense supply required will be procured from Ceylon, Burmah, Andaman Islands, and Australia; there will also be a regular and heavy drain on the forests of South India. About thirty kinds of indigenous woods have been used experimentally for sleepers; but the trials have not been attended, in some instances, with satisfactory results; not always because the woods were inferior, but from the timber not having reached a sufficient age, and from its being employed when imperfectly seasoned. Experience has been gained, and better prospects are dawning upon the companies in this great essential of railway operations. The chief engineer, Madras Railway, lately issued a useful circular to the officers of districts regarding the branding of sleepers, of which the following is an extract:- "At the time of passing the sleepers they must be branded with a letter, showing the kind of wood according to the table of specification. Zine labels are being prepared, which, being nailed to the sleeper, will remain legible even after its decay. These will not supersede the branding, but be used in addition to it." The results of observations by the engineers of the different railways hereafter published will be valuable; at present the summary of what is known is as follows:-Teak (Tectona grandis), is probably the best of all woods for sleepers, but is yearly becoming more scarce and costly. Sal (Vatica robusta), the next best wood, is not indigenous in any quantity south of Orissa, but is largely used in Bengal. Erul of Malabar (Inga xylocarpa), is a superior wood, and suitable for railway purposes. Jarra or Yarra (Eucalyptus rostrata), specially noticed in a despatch from Lord Stanley, has been lately imported in considerable quantity from Swan River. A timber trade with Australia would benefit the colony, and supply the Indian market with a substitute for teak. From the monthly returns of the engineers, showing the number of sleepers delivered on the different distriets of the Madras railway, and the trees furnishing them, the following results are obtained:-The largest number of sleepers are procured from the family Combretacea, and the genera Terminalia and Conocarpus, remarkable for the height and size of their trunks, and the toughness of their timber. The durability under ground has not been altogether satisfactory. Cadukai (Terminalia (hebula) appears to be liable both to the attack of fungi and of the carpenter bee. The Leguminosce are next in importance, the trees supplying the wood being Pterocarpas (Véngé), Inga (Erúl), Hardwickia (Acha), and various species of A cacia. Well-grown timber of these kinds is deservedly prized by the engineers. As the native name frequently applies to a genus rather than to a species, it is doubtful whether those marked Sal and Pedowk, are really the true species, although obtained from trees belonging to the genera Vatica and Pterocarpus. 'The railway engineers generally have confidence in SaI, llúpe (Bassia), KaraMarda, Véngé, Chella-Wunjé. Teak being too expensive for general use as sleepers, it has recently been proposed to substitute sleepers of castiron for those of wood, and the plan has already been carried out on a large scale; it is thought that iron will in the end be found the most economical material for sleepers. The Indian woods, which as yet appear to be best adapted for trenails and wedges, are Kara-Marda (Pentaptera coriacea), and Sal (Vatica robusta); the former for trenails, the latter for wedges. They resist the attacks of white ants, which destroy the beech and elm imported from England. 
Professor Balfour stated to the meeting, that a Botanical Society had been recently organised at Kingston, Canada West, having for its object the thorough investigation of the Canadian Flora, as well as the prosecution of the science of botany in general. The Society seems to have a similar constitution to that of the Edinburgh Botanical Society. At the first meeting, held at Kingston on Friday, 7 th December last, there was a large attendance of gentiemen from all parts of the country; and, after addresses had been delivered by the Rev. Principal Leitch, Professor George Lawson, and Professor Litchfield, upwards of 100 were enrolled as members of the Society.

T. C. Archer, Esq., exhibited a hunting-net, which had been sent to the Industrial Museum by Dr Livingston from Africa, manufactured by the natives from the bark of the Baobab tree (Adansonia digitata.)

\section{4th February 1861.-Dr W. H. Lowe, President, in the Chair.}

The following donations to the Society's Library were laid on the table :-

Transactions of the Tyneside Naturalist's Field Club, Vol. IV. Part 4, from the Club.

The Technologist for February, from the Editor.

The following Donations to the Herbarium were announced :-

From Dr E. Dubuc-Arabian plants.

From Rev, A. M. Norman, Ferryhill, Durham-British plants.

From Mr H. Ibbotson, York-British plants.

The following Donations to the Museum of Economic Botany at the Botanic Garden were noticed:-

From Dr John Brown-The Cane of the Rev. James Brown, given by his son, Robert Brown, Esq., F.R.S., \&c., on his deathbed, to Dr Boott, June 1858.

From Daniel Hanbury, Esq., London-Fruit of Myroxylon Pereirce, Balsam of Peru plant.

The following Communications were read :-

TRANS. BOT. SOC., VOL. VIT. 